\title{
Hubungan Interaksi Edukatif Guru dengan Siswa terhadap Minat Belajar Siswa pada Mata Pelajaran Sejarah Kebudayaan Islam (SKI) di MA Al- Hidayah Ibun
}

\author{
Rizki Zakiyah Nur Rohmah*, Helmi Aziz
}

Prodi Pendidikan Agama Islam, Fakultas Tarbiyah dan Keguruan, Universitas Islam Bandung, Indonesia.

*rizki.zakiyahnr@gmail.com, helmiaziz87@gmail.com

\begin{abstract}
The problem that occurs at MA Al-Hidayah Ibun in learning Islamic Cultural History (SKI) is the one-way teaching and learning interaction that makes the teacher's role very dominant and learning becomes passive. Only students can get the information provided by their teacher, the teacher who is talking about it is very active and students become passive. This study uses a quantitative approach to the type of correlational research that is to find the relationship between variable $\mathrm{x}$ and variable $\mathrm{y}$. Data collection methods used in this study are through questionnaires, observations, interviews and documentation. The results of this study indicate that: (1) The tendency of teacher-student interaction variables is $10 \%$ ( 3 students) in the high category, $73.4 \%$ (22 students) is in the medium category, and 16.6\% (5 students) is in the low category. These results indicate that the educative interaction of teachers with students in the MA Al-Hidayah Ibun included in the medium category. (2) The tendency of students' interest in learning variables in SKI subjects is $13.3 \%$ (4 students) in the high category, $70 \%$ (21 students) is in the medium category, and 16.7\% (5 students) are in the low category. These results indicate that students' interest in learning SKI subjects in MA Al-Hidayah Ibun is included in the medium category. (3) There is a significant correlation between teacher's educational interactions with students on student learning interest in History subjects Islamic Culture at MA Al-Hidayah Ibun. This is evidenced through hypothesis testing using product moment correlation, obtained correlation coefficient value $\mathrm{r}$ count $=$ 0.5304 , then consulted with the value of $\mathrm{r}$ product moment with $\mathrm{n}=30$ at a significant level of $5 \%$ or 0.05 , 0.361 . Then the conclusion is that $r$ count $>r$ table, so Hypothesis 1 is accepted.
\end{abstract}

\section{Keywords: Educational Interaction, Learning Interest, Students}

\begin{abstract}
Abstrak. Permasalahan yang terjadi di MA Al-Hidayah Ibun dalam pembelajaran Sejarah Kebudayaan Islam (SKI) adalah terjadinya interaksi belajar mengajar satu arah yang menjadikan peran guru sangat dominan dan pembelajaran pun menjadi pasif. Sehingga siswa hanya mendengarkan informasi yang diberikan oleh gurunya, yang akibatnya guru sangat aktif dan siswa menjadi pasif. Penelitian ini menggunakan pendekatan kuantitatif dengan jenis penelitian korelasional yaitu untuk mencari hubungan antara variabel x dan variabel y. Metode pengumpulan data yang digunakan dalam penelitian ini yaitu melalui angket, observasi, wawancara dan dokumentasi. Hasil penelitian ini menunjukkan bahwa: (1) Kecenderungan variabel interaksi guru dengan siswa yaitu sebanyak $10 \%$ (3 siswa) berada pada kategori tinggi, sebanyak 73,4 \% (22 siswa) berada pada kategori sedang, dan 16,6\% (5 siswa) berada pada kategori rendah. Hasil ini menunjukkan bahwa interaksi edukatif guru dengan siswa di MA Al-Hidayah Ibun termasuk pada kategori sedang. (2) Kecenderungan variabel minat belajar siswa pada mata pelajaran SKI yaitu sebanyak 13,3 \% (4 siswa) berada pada kategori tinggi, sebanyak $70 \%$ (21 siswa) berada pada kategori sedang, dan 16,7\% (5 siswa) berada pada kategori rendah. Hasil ini menunjukkan bahwa minat belajar siswa pada mata pelajaran SKI di MA Al-Hidayah Ibun termasuk pada kategori sedang.3) Terdapat hubungan yang signifikan antara interaksi edukatif guru dengan siswa terhadap minat belajar siswa pada mata pelajaran Sejarah Kebudayaan Islam (SKI) di MA Al-Hidayah Ibun. Hal ini dibuktikan melalui uji hipotesis menggunakan korelasi product moment, diperoleh nilai koefisien korelasi $\mathrm{r}_{\text {hitung }}=0,5304$, kemudian dikonsultasikan dengan nilai $\mathrm{r}$ product moment dengan $\mathrm{n}=30$ pada taraf signifikan $5 \%$ atau 0,05 yaitu 0,361. Maka diambil kesimpulan bahwa $r_{\text {hitung }}>r_{\text {tabel }}$, sehingga Hipotesis 1 diterima.
\end{abstract}

Kata Kunci: Interaksi Edukatif, Minat Belajar, Siswa 


\section{A. Pendahuluan}

Pembelajaran merupakan perpaduan dari dua aktivitas, yaitu aktivitas mengajar dan belajar yang didalamnya terdiri dari seorang guru dan siswa. Aktivitas mengajar menyangkut peranan seorang guru dalam menciptakan iklim kelas yang menyenangkan agar terciptanya komunikasi yang harmonis antara guru dan siswa. Hal ini berkaitan dengan salah satu kompetensi yang harus dimiliki seorang guru yaitu kompetensi sosial, dimana seorang guru harus mampu berinteraksi dengan siswanya dengan baik. Interaksi antara guru dengan siswa yang tercipta dalam suatu pembelajaran disebut interaksi edukatif. Interaksi edukatif merupakan interaksi dua arah antara guru dengan siswa yang berlangsung dalam ikatan tujuan pembelajaran sehingga terciptanya interaksi yang aktif antara keduanya (Djamarah, 2014: 11). Oleh karena itu, interaksi edukatif perlu dibedakan dari bentuk interaksi yang lain, yakni interaksi yang ada dalam pembelajaran disebut dengan inteaksi belajar mengajar.

Kegiatan belajar mengajar merupakan suatu kondisi dimana guru memberikan ilmu dan membimbing siswa dalam suatu pembelajaran. Dalam kegiatan belajar mengajar terdapat dua unsur yaitu guru yang mengajar, dan siswa yang belajar. Perpaduan dari kedua unsur ini diharapkan dapat menciptakan suatu interaksi edukatif yang baik antara pendidik dan peserta didik. Mengingat begitu pentingnya interaksi edukatif dalam suatu proses pembelajaran, seorang guru harus mampu menciptakan komunikasi yang baik dengan peserta didik melalui interaksi edukatif agar materi yang disampaikan dapat dipahami oleh peserta didik. Maka interaksi ini harus terjadi secara dua arah, dan tugas guru dalam mengajar tidak hanya sebatas pada "transfer of knowledge" tetapi juga "transfer of values", sehingga peserta didik tidak hanya meperoleh ilmu pengetahuan, tetapi bisa mengaplikasikannya dalam kehidupan seharihari.

Permasalahan yang sering terjadi dalam suatu pembelajaran adalah terjadinya interaksi belajar mengajar satu arah yang menjadikan peran guru sangat dominan dan pembelajaran pun menjadi pasif. Sehingga siswa hanya mendengarkan informasi yang diberikan oleh gurunya, yang akibatnya guru sangat aktif dan siswa menjadi pasif dan tidak kreatif. Disamping begitu pentingnya interaksi edukatif dalam suatu pembelajaran, minat juga terkait di dalamya. Karena tinggi atau rendahnya minat seorang siswa dalam belajar dapat mempengaruhi konsentrasi dan perhatian siswa pada pelajaran. Ketika siswa memiliki minat yang tinggi terhadap suatu pembelajaran, maka ia akan tertarik untuk mempelajarinya, memperhatikan serta belajar dengan sebaik mungkin ketika pembelajaran berlangsung.

Berdasarkan latar belakang yang telah diuraikan, maka perumusan masalah dalam penelitian ini adalah "Bagaimana interaksi edukatif guru dengan siswa di Madrasah Aliyah (MA) Al-Hidayah Ibun, minat belajar siswa MA Al-Hidayah Ibun terhadap mata pelajaran SKI, dan Seberapa besar hubungan antara interaksi edukatif guru dengan siswa terhadap minat belajar siswa pada mata pelajaran SKI di MA Al-Hidayah Ibun?". Selanjutnya, tujuan penelitian ini ialah untuk mengidentifikasi:

1. Interaksi edukatif antara guru dengan siswa MA Al-Hidayah Ibun.

2. Minat belajar siswa MA Al-Hidayah Ibun terhadap mata pelajaran SKI.

3. Hubungan interaksi edukatif guru dengan siswa terhadap minat belajar pada mata pelajaran SKI di MA Al-Hidayah Ibun.

\section{B. Landasan Teori}

Menurut Djamarah (2014:11) interaksi edukatif merupakan interaksi dua arah antara guru dengan siswa yang berlangsung dalam ikatan tujuan pembelajaran sehingga terciptanya interaksi yang aktif antara keduanya Sedangkan menurut Syuhadi dan Achmadi (1985: 47) interaksi edukatif harus mengambarkan hubungan aktif dua arah dengan sejumlah pengetahuan yang dijadikan perantara, sehingga interaksi guru dengan siswa diartikan dengan hubungan yang bermakana dan kreatif. Semua unsur interaksi harus berproses pada ikatan tujuan pembelajarn yang hendak dicapai. Dengan demikian dapat dipahami bahwa interaksi yang terjadi dalam pembelajaran disebut interaksi edukatif. Interaksi edukatif merupakan hubungan atau interaksi dua arah antara guru dengan siswa yang terjalin antara guru dengan siswa sehingga tercapainya 
tujuan pembelajaran. Oleh karena itu, dalam suatu pembelajaran harus tercipta interaksi dua arah antara guru dengan siswa agar terciptanya suasana belajar yang kondusif.

Proses pembelajaran akan berjalan dengan lancar apabila interaksi antara guru dengan siswa berjalan dengan baik dan didukung oleh komponen yang terdapat dalam pembelajaran. Menurut Mulyasa (2004: 156) indikator yang digunakan sebagai tolak ukur interaksi edukatif yaitu adanya keterlibatan siswa dalam pembelajaran baik keterlibatan emosial maupun mental, dan adanya kontribusi siswa dalam rangka mencapai tujuan pembelajarn.Sedangkan menurut Iriantara (2013: 76) ciri-ciri adanya interaksi positif antara guru dengan siswa antara lain:

1. Siswa didorong agar berpartisipasi aktif dalam pembelajaran.

2. Memiliki hubungan yang baik antara guru dengan siswa.

3. Guru mengajukan pertanyaan kepada siswa guna menguatkan penalaran siswa.

4. Menggunakan pertanyaan yang mendorong penalaran tingkat tinggi.

5. Guru mampu menjawab berbagai pertanyaan yang diajukan oleh siswa.

6. Guru berperan sebagai pembimbing dan pendamping siswa.

7. Terampil dalam berinteraksi, untuk mencegah adanya kebosanan.

8. Guru mampu memecahkan permasalahan yang terjadi baik itu berkaitan dengan pembelajaran maupun masalah pribadi siswa.

Dalam Penelitian ini indikator interaksi edukatif yang dipakai oleh peneliti yaitu: a) Terampil dalam berinteraksi untuk mencegah kebosanan, b) Memiliki kemampuan komunikasi yang baik antara guru dengan siswa, c) Siswa didorong agar berpartisipasi aktif dalam pembelajaran, e) Guru berperan sebagai pembimbing dan pendamping siswa.

Disamping begitu pentingnya interaksi edukatif antara guru dengan siswa, minat juga terkait di dalamnya. Karena tinggi atau rendahnya minat seorang siswa dalam belajar dapat mempengaruhi konsentrasi dan perhatian siswa dalam belajar. Ketika siswa minat dalam belajar, maka siswa akan tertarik untuk mempelajari pelajaran dengan sungguh-sungguh karena menjadikan mata pelajaran tersebut sebagai sesuatu yang dibutuhkan. Minat merupakan suatu rasa lebih suka dan rasa ketertarikan pada suatu hal atau aktivitas yang timbul dari dalam diri. Minat pada dasarnya adalah penerimaan akan suatu hubungan antara diri sendiri dengan suatu di luar diri (Slameto, 2010: 180). Sedangkan menurut Erhamwilda (2016: 42) minat merupakan ketertarikan pada satu hal yang bisa berupa kegiatan, peristiwa, objek, makhluk, tempat, atau situasi tertentu yang akan menentukan apakah individu akan memperhatikannya atau tidak. Dengan kata lain sesuatu yang diminati akan diperhatikan, dan sebaliknya sesuatu yang tidak diminati tidak akan diperhatikan. Berdasarkan beberapa teori yang telah dikemukakan, dapat disimpulkan bahwa minat merupakan rasa suka atau ketertarikan terhadap suatu hal atau aktivitas yang menimbulkan suatu kecenderungan. Minat senantiasa berkaitan dengan segala aktivitas, termasuk belajar.

Menurut Djamarah (2011: 12) belajar adalah suatu kegiatan yang melibatkan dua unsur dalam diri yakni jiwa dan raga. Gerak raga yang ditunjukkan harus sejalan dengan dengan proses jiwa agar menciptakan suatu perubahan dalam diri. Perubahan sebagai hasil belajar merupakan perubahan yang mempengaruhi tingkah laku seseorang. Belajar merupakan proses terjadinya perubahan perilaku individu yang meliputi perilaku yang tampak dan perilaku yang tidak tampak yang menyangkut salah satu, dua, tiga, atau keseluruhan aspek kepribadian individu melalui proses yang direncanakandengan sengaja maupun melalui pengalaman yang tidak disengaja dalam lingkungan yang khusus maupun lingkungan alamiah (Erhamwilda, 2016: 117). Dapat disimpulkan bahwa belajar merupakan suatu proses usaha yang dilakukan secara sengaja maupun tidak sengaja untuk memperoleh perubahan tingkah laku sebagai hasil dari pengalamannya.

Berdasarkan teori minat dan teori belajar diatas, minat belajar merupakan rasa suka atau ketertarikan terhadap suatu pelajaran sehingga menimbulkan kecenderungan terhadap pelajaran yang disukai. Minat belajar juga bisa dipengaruhi beberapa faktor, diantaranya yaitu dipengaruhi oleh interaksi edukatif antara guru dengan siswa. hal ini sesuai dengan pendapat Slameto (2010: 54) bahwa interaksi edukatif guru dengan siswa termasuk kedalam faktor eksternal yang dapat mempengaruhi minat belajar siswa. 
Ada beberapa indikator minat yang dijadikan acuan oleh guru sehingga guru dapat membedakan mana siswa yang berminat untuk belajar dan mana siswa yang tidak berminat dalam belajar. Menurut Slameto (2010: 58) ada beberapa ciri yang menjadi indikator siswa berminat dalam belajar, diantaranya sebagai berikut: a) Mempunyai kecenderungan yang tetap untuk memperhatikan dan senang mempelajari pelajjaran yang ia minati secara terus menurus, b) Adanya rasa suka untuk mempelajari pelajaran yang diminati, c) Ada rasa keterikatan untuk mempelajari yang diminati, d) Lebih memprioritaskan hal yang diminati daripada yang lain, dan e) Direalisasikan melalui keterlibatan siswa dalam pembelajaran.Sedangkan menurut Djamarah (2011: 132) indikator minat belajar yaitu rasa suka atau senang, pernyataan menyukai, adanya rasa ketertarikan terhadap suatu hal, adanya inisiatif untuk belajar tanpa adanya suruhan, berpartisipasi dalam pembelajaran dan memperhatikan apa yang disampaikan. Dari beberapa pemaparan mengenai indikator interaksi edukatif, dalam penelitian ini peneliti menggunakan indikator minat yaitu perasaan senang, keterlibatan siswa dalam pembelajaran, ketertarikan terhadap mata pelajaran yang dipelajari, serta perhatian siswa terhadap mata pelajaran yang dipelajari.

\section{Hasil Penelitian dan Pembahasan}

\section{Interaksi Edukatif Guru dengan Siswa di MA Al-Hidayah Ibun}

Berdasarkan hasil perhitungan total skor terhadap angket penelitian tentang interaksi edukatif guru dengan siswa di MA Al-Hidayah Ibun, diperoleh skor tertinggi dari angket yaitu sebesar 57 dan skor terendah yaitu sebesar 37. Untuk memperjelas data interaksi edukatif guru dengan siswa di atas, maka akan disajikan pada tabel distribusi frekuensi. Sebelum membuat tabel distribusi frekuensi. Sebelum membuat tabel distribusi frekuensi, terlebih dahulu dihitung range, banyak kelas, dan panjang interval yang selanjutnya disajikan dalam bentuk tabel distribusi frekuensi.

1. Range

$$
\begin{aligned}
\mathrm{R} & =\text { Data tertinggi }- \text { Data terendah } \\
& =57-37 \\
& =20
\end{aligned}
$$

2. Banyak Kelas

$$
\begin{aligned}
\mathrm{K} & =1+3,3 \log n \\
& =1+3,3 \log 30 \\
& =1+3,3(1,47) \\
& =1+4,581 \\
& =5,861 \\
& =5 / 6
\end{aligned}
$$

3. Panjang Interval

$$
\begin{aligned}
\mathrm{P} & =\mathrm{R} / \mathrm{K} \\
& =20 / 5 \\
& =4
\end{aligned}
$$

Adapun tabel distribusi frekuensi interaksi edukatif guru dengan siswa dapat dilihat pada tabel berikut:

Tabel 1. Distribusi frekuensi interaksi edukatif guru dengan siswa

\begin{tabular}{|c|c|c|c|c|c|c|}
\hline No & Interval Kelas & $\mathrm{Fi}$ & $\mathrm{Xi}$ & $\mathrm{FiXi}$ & $\mathrm{Ci}$ & $\mathrm{FiCi}$ \\
\hline 1 & $37-40$ & 3 & 38,5 & 115,5 & -2 & -6 \\
\hline 2 & $41-44$ & 4 & 42,5 & 170 & -1 & -4 \\
\hline 3 & $45-48$ & 11 & 46,5 & 511,5 & 0 & 0 \\
\hline
\end{tabular}




\begin{tabular}{|c|c|c|c|c|c|c|}
\hline 4 & $49-52$ & 9 & 50,5 & 454,5 & 1 & 9 \\
\hline 5 & $53-56$ & 2 & 54,5 & 109 & 2 & 4 \\
\hline 6 & $57-60$ & 1 & 58,5 & 58,5 & 3 & 3 \\
\hline \multicolumn{2}{|c|}{ JUMLAH } & 30 & 291 & 1419 & & 6 \\
\hline
\end{tabular}

Dari tabel distribusi frekuensi diatas, dapat diketahui nilai rata-rata (mean) skor interaksi edukatif guru dengan siswa sebesar 47,3 , nilai modus atau perkiraan data yang sering muncul yaitu 47,58, nilai median atau nilai tengah yaitu 47,36, dan standar deviasi sebesar 4,74. Selanjutnya dapat dilakukan pengkategorian pada Variabel $\mathrm{X}$ yaitu interaksi edukatif guru dengan siswa. Untuk melakukan pengategorian tersebut menggunakan tabel persyaratan pengkategorian skor dengan ketentuan sebagai berikut:

Tabel 2. persyaratan pengkategorian skor

\begin{tabular}{|c|c|}
\hline Kategori & Ketentuan \\
\hline Tinggi & $\geq$ rata-rata + standar deviasi \\
\hline Sedang & rata-rata - standar deviasi s/d rata-rata + standar deviasi \\
\hline Rendah & $\leq$ rata-rata - standar deviasi \\
\hline
\end{tabular}

Berdasarkan ketentuan tabel di atas, maka dilakukan perhitungan untuk mengklasifikasikan skor kecenderungan variabel interaksi edukatif guru dengan siswa (X). Untuk lebih lengkapnya dapat dilihat pada tabel di bawah ini:

Tabel 3. Pengklasifikasian skor kecenderungan variabel interaksi edukatif guru dengan siswa

\begin{tabular}{|c|c|c|c|}
\hline Kategori & Ketentuan & Frekuensi & Presentase \\
\hline Tinggi & $\geq 52,04$ & 3 & $10 \%$ \\
\hline Sedang & $42,56 \mathrm{~s} / \mathrm{d} 52,04$ & 22 & $73,4 \%$ \\
\hline Rendah & $\leq 42,56$ & 5 & $16,6 \%$ \\
\hline \multicolumn{2}{|l|}{ JUMLAH } & 30 & $100 \%$ \\
\hline
\end{tabular}

Dengan demikian, dapat disimpulkan bahwa kecenderungan variabel interaksi guru dengan siswa yaitu sebanyak $10 \%$ (3 siswa) berada pada kategori tinggi, sebanyak 73,4 \% (22 siswa) berada pada kategori sedang, dan 16,6\% (5 siswa) berada pada kategori rendah.

\section{Minat Belajar Siswa Pada Mata Pelajaran SKI}

Berdasarkan hasil perhitungan total skor terhadap angket penelitian tentang interaksi edukatif guru dengan siswa di MA Al-Hidayah Ibun, diperoleh skor tertinggi dari angket yaitu sebesar 56 dan skor terendah yaitu sebesar 37. Untuk memperjelas data interaksi edukatif guru dengan siswa di atas, maka akan disajikan pada tabel distribusi frekuensi. Sebelum membuat tabel distribusi frekuensi, terlebih dahulu peneliti akan mencari range, banyak kelas, dan panjang interval yang selanjutnya disajikan dalam bentuk tabel distribusi frekuensi.

1. Range

$$
\begin{aligned}
\mathrm{R} & =\text { Data tertinggi }- \text { Data terendah } \\
& =56-37 \\
& =19
\end{aligned}
$$

2. Banyak Kelas

$$
\begin{aligned}
\mathrm{K} & =1+3,3 \log _{\mathrm{n}} \\
& =1+3,3 \log _{30} \\
& =1+3,3(1,47) \\
& =1+4,581 \\
& =5,861 \\
& =5 / 6
\end{aligned}
$$


3. Panjang Interval

$$
\begin{aligned}
\mathrm{P} & =\frac{R}{K} \\
& =\frac{19}{5} \\
& =3,8 \\
& =3 / 4
\end{aligned}
$$

Adapun tabel distribusi frekuensi interaksi edukatif guru dengan siswa dapat dilihat pada tabel berikut:

Tabel 4. Distribusi frekuensi interaksi edukatif guru dengan siswa

\begin{tabular}{|c|c|c|c|c|c|c|}
\hline No & Interval Kelas & Fi & Xi & FiXi & Ci & FiCi \\
\hline 1 & $37-40$ & 3 & 38,5 & 115,5 & -2 & -6 \\
\hline 2 & $41-44$ & 5 & 42,5 & 212,5 & -1 & -5 \\
\hline 3 & $45-48$ & 12 & 46,5 & 558 & 0 & 0 \\
\hline 4 & $49-52$ & 7 & 50,5 & 353,5 & 1 & 7 \\
\hline 5 & $53-56$ & 3 & 54,5 & 163,5 & 2 & 6 \\
\hline \multicolumn{2}{|c|}{ JUMLAH } & 30 & 291 & 1403 & & 2 \\
\hline
\end{tabular}

Dari tabel distribusi frekuensi di atas, dapat diketahui nilai rata-rata (mean) skor interaksi edukatif guru dengan siswa sebesar 46,74 , nilai modus atau perkiraan data yang sering muncul yaitu 46,82, nilai median atau nilai tengah yaitu 46,82, dan standar deviasi sebesar 4,44.

Selanjutnya dapat dilakukan pengkategorian pada Variabel X yaitu interaksi edukatif guru dengan siswa. Untuk melakukan pengategorian tersebut menggunakan tabel persyaratan pengkategorian skor dengan ketentuan sebagai berikut:

Tabel 5. Persyaratan pengkategorian skor

\begin{tabular}{|c|c|}
\hline Kategori & Ketentuan \\
\hline Tinggi & $\geq$ rata-rata + standar deviasi \\
\hline Sedang & rata-rata - standar deviasi s/d rata-rata + standar deviasi \\
\hline Rendah & $\leq$ rata-rata - standar deviasi \\
\hline
\end{tabular}

Berdasarkan ketentuan tabel di atas, maka dilakukan perhitungan untuk mengklasifikasikan skor kecenderungan variabel interaksi edukatif guru dengan siswa (X). Untuk lebih lengkapnya dapat dilihat pada tabel di bawah ini:

Tabel 6. Pengklasifikasian skor kecenderungan variabel interaksi edukatif guru dengan siswa

\begin{tabular}{|c|c|c|c|}
\hline Kategori & Ketentuan & Frekuensi & Presentase \\
\hline Tinggi & $\geq 51,18$ & 4 & $13,3 \%$ \\
\hline Sedang & $42,3 \mathrm{~s} / \mathrm{d} \mathrm{51,18}$ & 21 & $70 \%$ \\
\hline Rendah & $\leq 42,3$ & 5 & $16,7 \%$ \\
\hline \multicolumn{2}{|l}{ JUMLAH } & 30 & $100 \%$ \\
\hline
\end{tabular}

Dengan demikian, dapat disimpulkan bahwa kecenderungan variabel interaksi guru dengan siswa yaitu sebanyak 13,3 \% (3 siswa) berada pada kategori tinggi, sebanyak $70 \%$ (22 siswa) berada pada kategori sedang, dan 16,7\% (5 siswa) berada pada kategori rendah. 


\section{Hubungan Interaksi Edukatif Guru dengan Siswa terhadap Minat Belajar Siswa pada Mata Pelajaran SKI}

Berdasarkan pengolahan data angket dari variabel $X$ (interaksi edukatif guru dengan siswa) dan variabel Y (minat belajar siswa pada mata pelajaran SKI), maka selanjutnya hipotesis dapat diuji kebenarannya untuk mencari hubungan antara variabel x dan variabel y. Adapun hipotesis dalam penelitian ini adalah:

$\mathrm{H}_{0}$ : Tidak terdapat hubungan yang signifikan antara interaksi edukatif guru dengan siswa terhadap minat belajar siswa pada mata pelajaran Sejarah Kebudayaan Islam (SKI) di MA AlHidayah Ibun.

$\mathrm{H}_{1}$ : Terdapat hubungan yang signifikan antara interaksi edukatif guru dengan siswa terhadap minat belajar siswa pada mata pelajaran Sejarah Kebudayaan Islam (SKI) di MA Al-Hidayah Ibun.

Pengujian hipotesis pada penelitian ini menggunakan rumus product moment untuk mencari koefisien korelasi antara kedua variabel. Adapun penghitungan korelasinya yaitu:

Diketahui:

$$
\begin{aligned}
& \mathrm{n} \quad=30 \quad \sum \mathrm{Y}=1407 \sum \mathrm{Y}^{2}=66581 \\
& \sum \mathrm{X}=1429 \sum \mathrm{X}^{2}=68773 \sum \mathrm{XY}=67363 \\
& \mathrm{r}_{\mathrm{xy}}=\frac{n \sum x y-\sum x \sum y}{\sqrt{\left\{n \sum x^{2}-\left(\sum x\right)^{2}\right\} \cdot\left\{n \sum y^{2}-\left(\sum y\right)^{2}\right\}}} \\
& =\frac{30(67363)-(1429)(1407)}{\sqrt{\left\{30(68773)-(1429)^{2}\right\}}\left\{30(66581)-(1407)^{2}\right\}} \\
& =\frac{2020890-2010603}{\sqrt{\{2063190-2042041\}\{1997430-1979649\}}} \\
& =\frac{10287}{\sqrt{\{21149\}\{17781\}}} \\
& =\frac{10287}{\sqrt{376050369}} \\
& =\frac{10287}{19392,01} \\
& =0,5304
\end{aligned}
$$

Berdasarkan hasil analisis data menggunakan korelasi product moment, diperoleh nilai koefisian korelasi $\mathrm{r}_{\text {hitung }}=0,5304$, kemudian dikonsultasikan dengan nilai $\mathrm{r}$ product moment dengan $\mathrm{n}=30$ pada taraf signifikan $5 \%$ atau 0,05 yaitu 0,361. Maka diambil kesimpulan bahwa $\mathrm{r}_{\text {hitung }}>\mathrm{r}_{\text {tabel, }}$ yaitu $0,5304>0,361$. Hal ini berarti $\mathrm{H}_{1}$ diterima yaitu bahwa terdapat hubungan yang signifikan antara interaksi edukatif guru dengan siswa terhadap minat belajar siswa pada mata pelajaran Sejarah Kebudayaan Islam (SKI) di MA Al-Hidayah Ibun. Signifikansi antara interaksi edukatif dengan minat belajar sebesar 53,04\%, sedangkan sisanya dipengaruhi oleh faktor lain.

\section{Kesimpulan}

Berdasarkan pembahasan dalam penelitian ini, peneliti menyimpulkan beberapa hasil penelitian sebagai berikut:

1. Kecenderungan variabel interaksi guru dengan siswa yaitu sebanyak $10 \%$ (3 siswa) berada pada kategori tinggi, sebanyak 73,4 \% (22 siswa) berada pada kategori sedang, dan $16,6 \%$ (5 siswa) berada pada kategori rendah. Hasil ini menunjukkan bahwa interaksi edukatif guru dengan siswa di MA Al-Hidayah Ibun termasuk pada kategori sedang.

2. Kecenderungan variabel minat belajar siswa pada mata pelajaran SKI yaitu sebanyak $13,3 \%$ (4 siswa) berada pada kategori tinggi, sebanyak $70 \%$ (21 siswa) berada pada kategori sedang, dan 16,7\% (5 siswa) berada pada kategori rendah. Hasil ini menunjukkan bahwa minat belajar siswa pada mata pelajaran SKI di MA Al-Hidayah Ibun termasuk pada kategori sedang.

3. Berdasarkan hasil analisis data diperoleh kesimpulan bahwa terdapat hubungan yang signifikan antara interaksi edukatif guru dengan siswa terhadap minat belajar siswa pada mata pelajaran Sejarah Kebudayaan Islam (SKI) di MA Al-Hidayah Ibun. Hal ini 
dibuktikan melalui uji hipotesis menggunakan korelasi product moment, diperoleh nilai koefisien korelasi rhitung $=0,5304$, kemudian dikonsultasikan dengan nilai $\mathrm{r}$ product moment dengan $\mathrm{n}=30$ pada taraf signifikan $5 \%$ atau 0,05 yaitu 0,361 . Maka diambil kesimpulan bahwa rhitung $>$ rtabel. Hal ini berarti signifikansi antara interaksi edukatif dengan minat belajar sebesar 53,04\%, sedangkan sisanya dipengaruhi oleh faktor lain.

\section{E. Saran}

Berdasarkan pembahasan dalam penelitian ini, peneliti menyimpulkan beberapa hasil penelitian sebagai berikut:

1. Kepada kepala sekolah MA Al-Hidayah Ibun untuk mengadakan pembinaan terhadap semua guru guna meningkatkan kompetensi yang dimiliki sehingga menjadi guru yang berkualitas.

2. Kepada guru MA Al-Hidayah Ibun khususnya pada mata pelajaran SKI agar senantiasa mendampingi siswa dalam setiap pembelajaran, membimbing siswa jika mengalami kesulitan dalam belajar dan mengerjakan tugas agar terciptanya interaksi edukatif yang baik antara guru dengan siswa yang diharapkan dapat meningkatkan minat siswa dalam belajar.

3. Kepada Siswa MA Al-Hidayah Ibun agar senantiasa antusias dalam mempelajari suatu pembelajaran, mempelajari kembali yang telah dipelajari di sekolah, serta senantiasa konsentrasi dan bersungguh-sungguh dalam belajar.

\section{Daftar Pustaka}

[1] Aaker, A. David. 2002. Ekuitas Merek (Edisi Indonesia). Jakarta: Mitra Utama.

[2] Alma, Buchari. 2006. Manajemen Pemasaran dan Pemasaran Jasa. Bandung: Alvabeta.

[3] Arikunto, Suharsimi. 2006. Prosedur Penelitian Suatu Pendekatan Praktek. Jakarta: Rineka Cipta.

[4] Azwar, Syaifuddin. 2005. Metode Penelitian. Jogyakarta: Pustaka Belajar.

[5] Cangara, H. Hafied. 2002. Pengantar Ilmu Komunikasi. Jakarta: Raja Grafindo Persada.

[6] Darmadi, Sugianto dkk. 2010. Inovasi Pasar dengan Iklan yang Efektif (Strategi, Program dan Teknik Pengukuran). Jakarta: Gramedia Pustaka Utama.

[7] Durianto, Darmadi dan C. Liana. 2001. Analisis Efektifitas Iklan Televisi Softener Soft \& Fresh di Jakarta dan Sekitarnya dengan Menggunakan Consumer Decision Model. Jurnal Ekonomi Perusahaan. Volume IV Nomor[1] Djamarah, Syaiful Bahri. (2014). Guru dan Anak Didik dalam Interaksi Edukatif. Jakarta: PT Rineka cipta.

[2] Djamarah, Syaiful Bahri. (2014). Guru dan Anak Didik dalam Interaksi Edukatif. Jakarta: PT Rineka cipta.

[3] Iriantara, Y. (2013). Komunikasi Pendidikan. Bandung: PT Remaja Rosdakarya.

[4] Achmadi, Abu dan Syuhadi. (1985). Psikologi Belajar. Jakarta: Rineka Cipta.

[5] Mulyasa, E. (2004). Kurikulum Berbasis Kompetensi. Bandung: Remaja Rosdakarya.

[6] Erhamwilda. (2016). Psikologi Belajar Islami. Bandung: PG-PAUD Fakultas Tarbiyah dan Keguruan Unisba.

[7] Djamarah, Syaiful Bahri. (2011). Psikologi Belajar. Jakarta: Rineka Cipta.

[8] Slameto. (2010). Belajar dan Faktor-Faktor Yang Mempengaruhinya. Jakarta: Rineka Cipta. 